Article

\title{
Dynamic Observation of Interfacial IMC Evolution and Fracture Mechanism of Sn2.5Ag0.7Cu0.1RE/Cu Lead-Free Solder Joints during Isothermal Aging
}

\author{
Di Zhao ${ }^{1,2,3}$, Keke Zhang ${ }^{1,2, *}$, Ning Ma ${ }^{1,2}$, Shijie Li ${ }^{1,2}$, Chenxiang Yin ${ }^{1,2}$ and Fupeng Huo ${ }^{4,5}$ \\ 1 School of Materials Science and Engineering, Henan University of Science and Technology, \\ Luoyang 471023, China; 19B909143@stu.hit.edu.cn (D.Z.); lsxzmn@163.com (N.M.); \\ lsjlishijieli@163.com (S.L.); yinyuxin416@foxmail.com (C.Y.) \\ 2 Henan Province Key Laboratory of Nonferrous Metal Material Science and Processing Technology, \\ Luoyang 471023, China \\ 3 State Key Laboratory of Advanced Welding and Joining, Harbin Institute of Technology, \\ Harbin 150001, China \\ 4 Joining and Welding Research Institute, Osaka University, 11-1 Mihogaoka, Ibaraki, Osaka 567-0047, Japan; \\ huofp@jwri.osaka-u.ac.jp \\ 5 Graduate School of Engineering, Osaka University, 2-1 Yamadaoka, Suita, Osaka 565-0871, Japan \\ * Correspondence: zhkeke@haust.edu.cn; Tel.: +86-0379-64276880
}

Received: 10 January 2020; Accepted: 4 February 2020; Published: 12 February 2020

\begin{abstract}
Dynamic observation of the microstructure evolution of Sn2.5Ag0.7Cu0.1RE/Cu solder joints and the relationship between the interfacial intermetallic compound (IMC) and the mechanical properties of the solder joints were investigated during isothermal aging. The results showed that the original single scallop-type $\mathrm{Cu}_{6} \mathrm{Sn}_{5}$ IMC gradually evolved into a planar double-layer IMC consisting of $\mathrm{Cu}_{6} \mathrm{Sn}_{5}$ and $\mathrm{Cu}_{3} \mathrm{Sn}$ IMCs with isothermal aging. In particular, the $\mathrm{Cu}_{3} \mathrm{Sn}$ IMC grew towards the $\mathrm{Cu}$ substrate and the solder seam sides; growth toward the $\mathrm{Cu}$ substrate side was dominant during the isothermal aging process. The growth of $\mathrm{Cu}_{3} \mathrm{Sn}$ IMC depended on the accumulated time at a certain temperature, where the growth rate of $\mathrm{Cu}_{3} \mathrm{Sn}$ was higher than that of $\mathrm{Cu}_{6} \mathrm{Sn}_{5}$. Additionally, the growth of the interfacial IMC was mainly controlled by bulk diffusion mechanism, where the activation energies of $\mathrm{Cu}_{6} \mathrm{Sn}_{5}$ and $\mathrm{Cu}_{3} \mathrm{Sn}$ were 74.7 and $86.6 \mathrm{~kJ} / \mathrm{mol}$, respectively. The growth rate of $\mathrm{Cu}_{3} \mathrm{Sn}$ was slightly faster than that of $\mathrm{Cu}_{6} \mathrm{Sn}_{5}$ during isothermal aging. With increasing isothermal aging time, the shear strength of the solder joints decreased and showed a linear relationship with the thickness of $\mathrm{Cu}_{3} \mathrm{Sn}$. The fracture mechanism of the solder joints changed from ductile fracture to brittle fracture, and the fracture pathway transferred from the solder seam to the interfacial IMC layer.
\end{abstract}

Keywords: $\mathrm{Sn} 2.5 \mathrm{Ag} 0.7 \mathrm{Cu} 0.1 \mathrm{RE} / \mathrm{Cu}$ soldering; dynamic observation; isothermal aging; intermetallic compound; growth kinetics; fracture mechanism

\section{Introduction}

In an electronic packaging system, solder joints provide an electrical connection and mechanical support to the electronic components. The need for function integration, high power, and density of the electronic products has been a driving force for highly reliable inter-connection solder joints [1,2]. Because of the inherent toxicity of lead, the use of $\mathrm{SnPb}$ solder has been restricted. Various types of environmental-friendly Sn-based lead-free alloys have been developed [3-7]. SnAgCu system lead-free solder alloys have been regarded as one of the promising candidates for $\mathrm{SnPb}$ solder alloys because of their good mechanical properties [8]. However, compared to the traditionally SnPd solders, the wettability $\mathrm{SnAgCu}$ lead-free solders are relatively poor. Additionally, the high $\mathrm{Ag}$ content of $\mathrm{SnAgCu}$ 
lead-free solders will lead to the formation of the brittle $\mathrm{Ag}_{3} \mathrm{Sn}$ phase. Apart from issues associated with properties and reliability, the cost is another issue to be considered. Rare earth (REs) also has a high chemical activity, which can effectively decrease the surface energy of molten alloys and thus improve the wettability of alloys. Xue and his team added $\mathrm{Ce}, \mathrm{Pr}$, and $\mathrm{Nd}$ in the SnAgCu solder alloys [9-13]. They found that the appropriate addition of Pr and Nd enhanced the shear bond strength of solder joints and refined the morphology of the interface layer. Yu et al. [14] found that with the addition of trace Ce and La elements, the $\beta$-Sn grains and eutectic colony in Sn3.5Ag0.7Cu alloy are refined. All these results indicated that adding trace rare earth elements was an efficient way to develop new solders. Our team has attempted to lower the Ag content by adding RE elements, obtaining quite promising results with the solder alloy of Sn2.5Ag0.7Cu0.1RE [15,16]. It is well known that the solder joints are frequently exposed to various harsh environments, such as temperature, humidity, shock, and vibration [17-19]. It was reported that approximately half the failure of the solder joints was caused by isothermal aging [20]. One of the most important reliability issues is the microstructure evolution of the solder joints, and understanding the growth behavior and kinetics of the interfacial intermetallic compound (IMC) is regarded as essential. In the literature, investigating the reliability of isothermal aging of Sn-based lead-free solder joints has become an area of interest. Many scholars have studied the isothermal aging characteristics of $\mathrm{SnAgCu} / \mathrm{Cu}$ [21-25], In-48Sn/Cu [26,27], and $\mathrm{Sn}-\mathrm{Bi} / \mathrm{Cu}[28,29]$ solder joints. They have focused on the growth kinetics of the interfacial IMC and the mechanical properties of solder joints during isothermal aging. $\mathrm{Xu}$ et al. [21] investigated the influence of isothermal time and temperature on the interfacial IMC layer growth of $\mathrm{Sn}-3.5 \mathrm{Ag}-0.5 \mathrm{Cu} / \mathrm{Cu}$ solder joints. Their studies showed that the interfacial IMC layer not only became thicker but also transformed from a scallop-like shape to planar shape with increasing isothermal aging time. Zhang et al. [22] reported the growth kinetics of the interfacial IMC layer of $\mathrm{Sn}-3.8 \mathrm{Ag}-0.7 \mathrm{Cu} / \mathrm{Cu}$ solder joints and found that the IMC growth was controlled by the diffusion mechanism. Besides, they obtained the activation energy of the interfacial IMC. Hu et al. $[23,24]$ further studied the relationships between the interfacial IMC and the fracture behavior of the $\mathrm{Sn}-3.0 \mathrm{Ag}-0.5 \mathrm{Cu} / \mathrm{Cu}$ solder joints during isothermal aging. Nishikawa and Iwata [25] compared the reflow soldering and laser soldering and found that the growth of the interfacial IMC layer was slower by reflow soldering at the isothermal aging temperature $423 \mathrm{~K}$. However, because of the slow reaction rate of the interfacial movement during isothermal aging, it is difficult to precisely measure the interfacial movement. To date, most methods used to investigate the growth kinetics and the interfacial movement during isothermal aging have used qualitative and statistical analysis [21-25], which cannot accurately reveal the constituents and growth of the interfacial IMC. Additionally, the relationship between the size and morphology of the interfacial IMC and the fracture mechanism of the solder joints during isothermal aging is not well understood.

Therefore, in this work, we conduct a dynamic observation of the interfacial IMC evaluation and the relationship between the growth behavior of interfacial IMC and the mechanical properties of the solder joints. There is important theoretical and practical value in predicting the reliability of solder joints.

\section{Materials and Methods}

\subsection{Materials and Soldering}

A Sn2.5Ag0.7Cu0.1RE solder alloy; pure metals of $\mathrm{Sn}, \mathrm{Ag}$, and $\mathrm{Cu}$ (purity 99.9\%); and a RE mixture (with approximately $40 \% \mathrm{La}$ and $60 \% \mathrm{Ce}$ ) were used as the raw materials. The solder alloy and $\mathrm{Cu}$ substrate were prepared according to the procedures described in reference [30]. After that, the soldering specimens were placed into the electric chamber furnace at $270{ }^{\circ} \mathrm{C}$ for $4 \mathrm{~min}$.

\subsection{Isothermal Aging}

To illustrate the interfacial movement quantitatively, marks were carved on the Cu substrate and used as reference points. The indentation was carried out by the MHV-2000 Micro-Vickers (Laizhou 
Huayin Testing Instrument Co., Ltd., Laizhou, China). After the indentation test, a rectangular pyramid mark could be found on the $\mathrm{Cu}$ substrate. The marks made by micro-Vickers are assumed to be fixed during isothermal aging. The specimens were aged at $100,125,150$, and $175{ }^{\circ} \mathrm{C}$ for $72,192,288$, and $360 \mathrm{~h}$ and the morphology of the solder joints was observed for each aging time. Additionally, to reduce the oxidation of the surface, the specimens were placed in a vacuum electric chamber furnace with the argon gas atmosphere (purity $>99.99 \%$ ).

\subsection{Characterization Methods}

The microstructure of the solder joints was obtained by a scanning electron microscope (SEM, JMS-5610LV, Tokyo, Japan), and the chemical composition was determined by energy dispersive spectroscopy (EDS, Inca X-sight, Oxford Instruments, Oxford, England), X-ray diffraction (XRD, Bruker D8-Advance, Billerica, MA, USA) patterns of the soldering samples were recorded on a Bruker D8 Advance $X$-ray diffractometer in $2 \theta$ ranging from $25^{\circ}$ to $80^{\circ}$. The shear strength tests were carried out in a UTM2503 universal testing machine (Shenzhen SUNS technology stock Co., Ltd., Shenzhen, China) at room temperature with a rate of $1 \mathrm{~mm} / \mathrm{min}$.

To describe the growth behavior of the interfacial IMC layer and interfacial movement, the distances between the mark ("P") and the interface of $\mathrm{Cu} / \mathrm{Cu}_{3} \mathrm{Sn}, \mathrm{Cu}_{3} \mathrm{Sn} / \mathrm{Cu}_{6} \mathrm{Sn}_{5}$, and $\mathrm{Cu}_{6} \mathrm{Sn}_{5} / \mathrm{Solder}$ were measured with increasing isothermal aging time, as illustrated in Figure 1. The distance between the interface and the marked point (" ${ }^{\prime \prime}$ ) was measured by the Image-Pro Plus 6.0 software (Media Cybernetics, Rockville, MD, USA). The average thickness of the interfacial IMC (d) was calculated by the Equation (1) [31]:

$$
d=A / L
$$

where $A$ is the area of interfacial IMC layers and $L$ represents the length of the coverage.

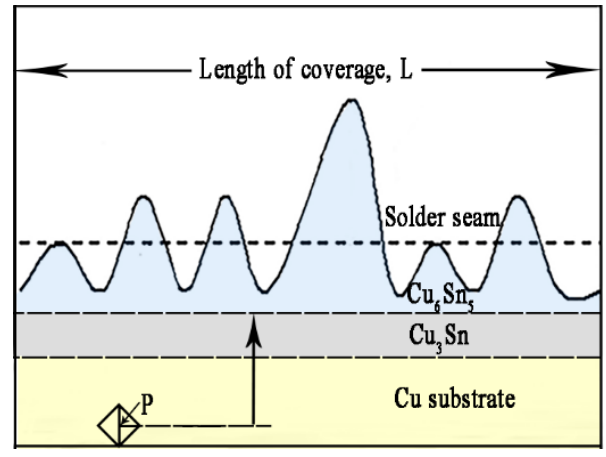

Figure 1. Schematic diagram of interfacial intermetallic compound.

\section{Results and Discussion}

\subsection{Interfacial IMC Evolution of the Sn2.5Ag0.7Cu0.1RE/Cu Solder Joints during Isothermal Aging}

Figure 2 shows the dynamic observation interfacial microstructure evolution during isothermal aging. The solder joints consisted of a soldering seam, interfacial IMC, and Cu substrate. The soldered seam included the primary $\beta$-Sn phase and eutectic phases which were presented at the boundary of the primary $\beta-S n$ region. The eutectic phases included the fine acicular $\beta-S n+A g_{3} S n$, granular $\beta-S n+\mathrm{Cu}_{6} \mathrm{Sn}_{5}$ binary eutectics, and the $\beta-\mathrm{Sn}+\mathrm{Ag}_{3} \mathrm{Sn}+\mathrm{Cu}_{6} \mathrm{Sn}_{5}$ ternary eutectic [32,33]. A continuous $\mathrm{Cu}_{6} \mathrm{Sn}_{5}$ interfacial IMC layer with a scallop-like morphology was formed between the $\mathrm{Cu}$ substrate and solder seam after soldering. In theory, the $\mathrm{Cu}_{3} \mathrm{Sn}$ IMC should exist between $\mathrm{Cu}$ and $\mathrm{Cu}_{6} \mathrm{Sn}_{5}$; however, $\mathrm{Cu}_{3} \mathrm{Sn}$ is often too thin after soldering to be detected by SEM [34]. With increasing isothermal aging time and temperature, the thickness of interfacial IMC layers clearly increased (Figure 2), and the morphology gradually evolved from scallop-type to planar because of the growth and the combination of adjacent scallop-like $\mathrm{Cu}_{6} \mathrm{Sn}_{5}$. In addition, the composition of the interfacial IMC also changed. 
After isothermal aging for $72 \mathrm{~h}$ at $175{ }^{\circ} \mathrm{C}$, the scallop-like $\mathrm{Cu}_{6} \mathrm{Sn}_{5}$ covered a newly generated layer (marked " $\mathrm{A}$ "), which was determined to be the $\mathrm{Cu}_{6} \mathrm{Sn}_{5}$ phase by EDS analysis (Figure 3a). Additionally, a distinct dark grey region below the $\mathrm{Cu}_{6} \mathrm{Sn}_{5}$ layer appeared (marked "B"), which was confirmed to be the $\mathrm{Cu}_{3} \mathrm{Sn}$ phase by EDS analysis (Figure $3 \mathrm{~b}$ ). Figure 4 shows the distribution of $\mathrm{Cu}$ and $\mathrm{Sn}$ atoms of "line 1 " in Figure 2 after isothermal aging at $175^{\circ} \mathrm{C}$ for $360 \mathrm{~h}$. It was obvious that the interfacial IMC layer consisted of two IMCs layers which were $\mathrm{Cu}_{6} \mathrm{Sn}_{5}$ and $\mathrm{Cu}_{3} \mathrm{Sn}$ IMC by the above analysis. This indicated that the double-layer IMC comprising $\mathrm{Cu}_{6} \mathrm{Sn}_{5}$ and $\mathrm{Cu}_{3} \mathrm{Sn}$ IMC gradually evolved from the original single $\mathrm{Cu}_{6} \mathrm{Sn}_{5} \mathrm{IMC}$. As can be seen from Figure 2, the growth rate of interfacial $\mathrm{Cu}_{3} \mathrm{Sn}$ $\mathrm{IMC}$ is not obvious as the isothermal aging temperature is less than $150{ }^{\circ} \mathrm{C}$, while the $\mathrm{Cu}_{3} \mathrm{Sn}$ IMC is observed with an isothermal aging temperature greater than or equal to $150{ }^{\circ} \mathrm{C}$.

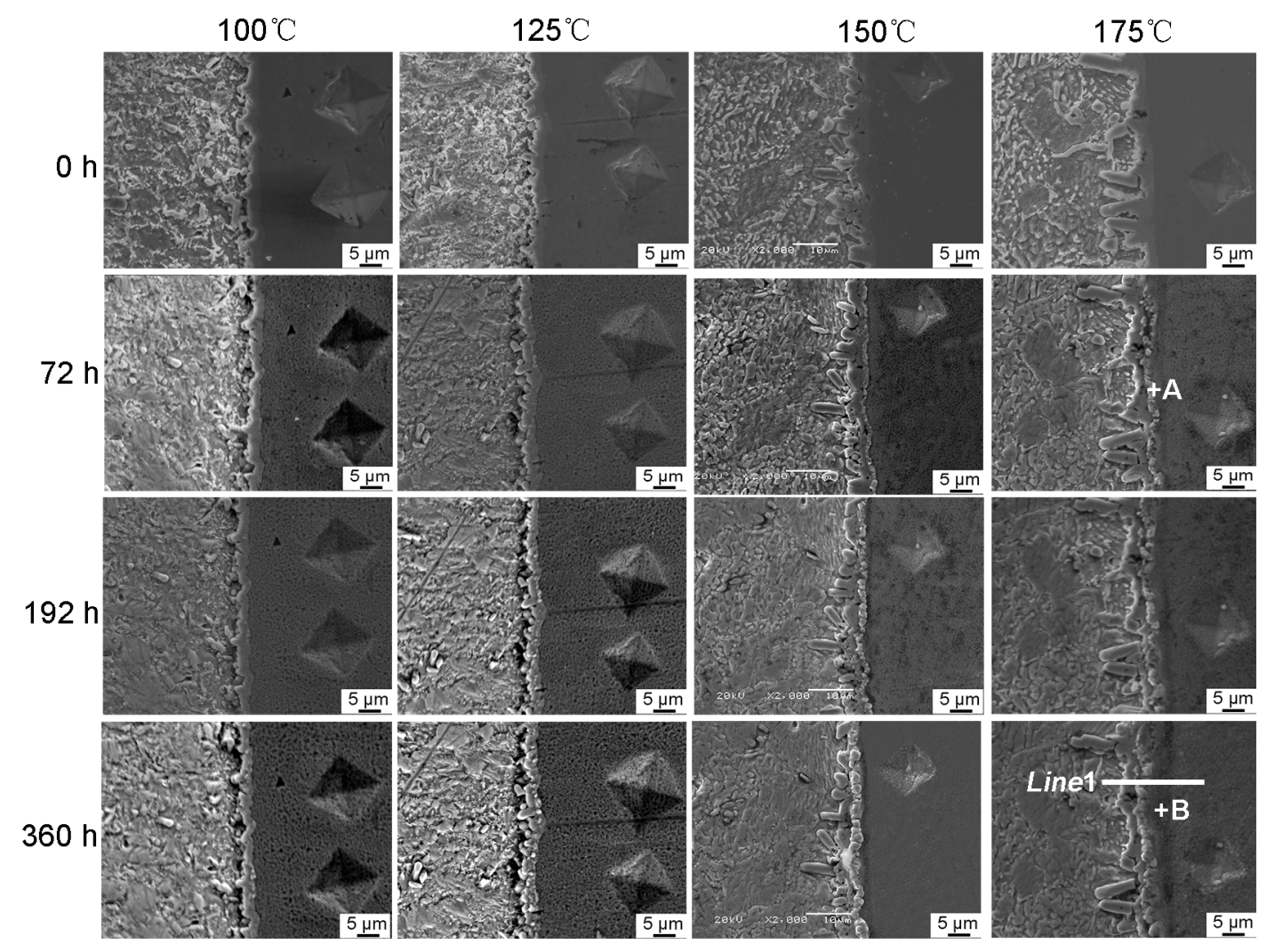

Figure 2. Cross-section micrographs of the interfacial IMC aged for different time and temperature.
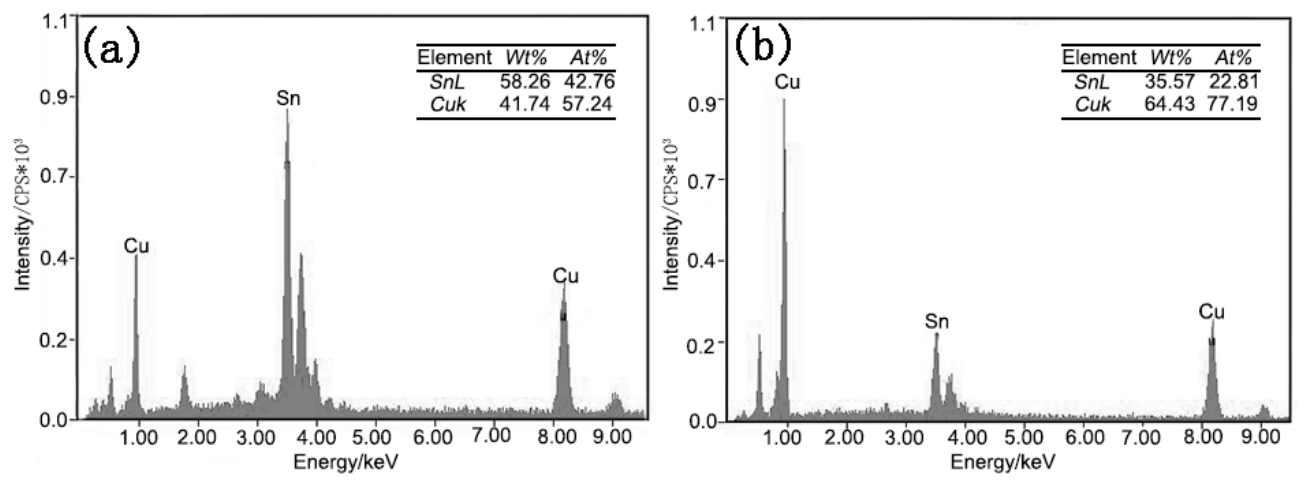

Figure 3. EDS analysis result of the point " $\mathrm{A}$ " and "B" in Figure 2. (a) point " $\mathrm{A}$ "; (b) point " $\mathrm{B}$ ". 


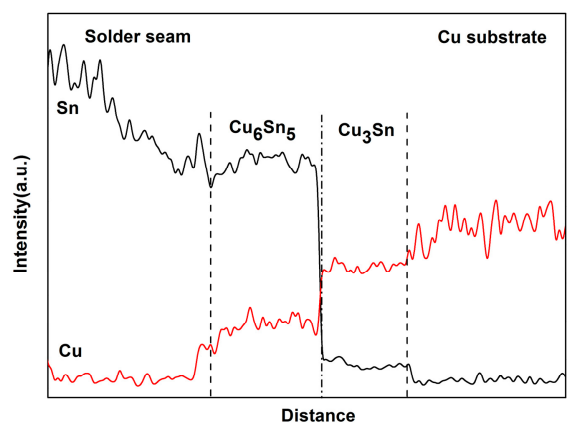

Figure 4. Elemental counts of the line "1" in Figure 2.

To further analyze the growth behavior of interfacial $\mathrm{Cu}_{6} \mathrm{Sn}_{5}$ and $\mathrm{Cu}_{3} \mathrm{Sn}$ IMCs, we investigated the interface migrations during isothermal aging at $175^{\circ} \mathrm{C}$. Based on the above analysis, the $\mathrm{Cu}_{3} \mathrm{Sn}$ IMC was not detected after soldering. Thus, it was assumed that there were only solder seam $/ \mathrm{Cu}_{6} \mathrm{Sn}_{5}$ and $\mathrm{Cu}_{6} \mathrm{Sn}_{5} / \mathrm{Cu}$ interfaces after soldering. To obtain the interfacial movement, the distances between the point "P" and the $\mathrm{Cu} / \mathrm{Cu}_{3} \mathrm{Sn}, \mathrm{Cu}_{3} \mathrm{Sn} / \mathrm{Cu}_{6} \mathrm{Sn}_{5}$, and $\mathrm{Cu}_{6} \mathrm{Sn}_{5} /$ solder interface were measured with the increase of isothermal aging time, as shown in Figure $5 \mathrm{~b}$. Compared with the original $\mathrm{Cu}_{6} \mathrm{Sn}_{5} / \mathrm{Cu}$ interface in Figure $5 \mathrm{a}$, when the isothermal aging time increased to $360 \mathrm{~h}$ (Figure $5 \mathrm{c}$ ), the relative distance from the $\mathrm{Cu} / \mathrm{Cu}_{3} \mathrm{Sn}, \mathrm{Cu}_{3} \mathrm{Sn} / \mathrm{Cu}_{6} \mathrm{Sn}_{5}$, and $\mathrm{Cu}_{6} \mathrm{Sn}_{5} /$ solder interfaces to the point "P" tended to decrease, slightly increase, and substantially increase, respectively. This indicated that with increasing isothermal aging time, the thickness of $\mathrm{Cu}_{6} \mathrm{Sn}_{5}$ increased, the $\mathrm{Cu}_{3} \mathrm{Sn}$ IMC formed at the original $\mathrm{Cu}_{6} \mathrm{Sn}_{5} / \mathrm{Cu}$ interface, and the $\mathrm{Cu}_{3} \mathrm{Sn}$ IMC grew towards both the $\mathrm{Cu}$ substrate and $\mathrm{Cu}_{6} \mathrm{Sn}_{5}$ sides. During isothermal aging, the original $\mathrm{Cu}_{6} \mathrm{Sn}_{5} / \mathrm{Cu}$ interface disappeared and gradually formed a $\mathrm{Cu}_{6} \mathrm{Sn}_{5} / \mathrm{Cu}_{3} \mathrm{Sn}$ and $\mathrm{Cu} / \mathrm{Cu}_{3} \mathrm{Sn}$ interface. This may be ascribed to the growth of interfacial IMC being dominated by the inter-diffusion of the $\mathrm{Sn}$ and $\mathrm{Cu}$ atoms during the isothermal aging process. $\mathrm{Cu}$ atoms from the $\mathrm{Cu}$ substrate diffused to the $\mathrm{Cu}_{3} \mathrm{Sn} / \mathrm{Cu}_{6} \mathrm{Sn}_{5}$ interface, and the following reaction occurred: $\mathrm{Cu}_{6} \mathrm{Sn}_{5}+15 \mathrm{Cu}=5 \mathrm{Cu}_{3} \mathrm{Sn}$ (reaction 1) [35]. Additionally, some $\mathrm{Sn}$ atoms may diffuse from the solder seam to the $\mathrm{Cu}_{3} \mathrm{Sn} / \mathrm{Cu}$ interface, and the reaction of $3 \mathrm{Cu}+\mathrm{Sn}=\mathrm{Cu}_{3} \mathrm{Sn}$ (reaction 2) occurred [35]. Therefore, the $\mathrm{Cu}_{3} \mathrm{Sn}$ layer grew to both sides, causing the $\mathrm{Cu} / \mathrm{Cu}_{3} \mathrm{Sn}$ interface to move to the $\mathrm{Cu}$ substrate side and the $\mathrm{Cu}_{6} \mathrm{Sn}_{5} / \mathrm{Cu}_{3} \mathrm{Sn}$ interface to move to the $\mathrm{Cu}_{6} \mathrm{Sn}_{5}$ side during isothermal aging. Paul et al. [36] used $\mathrm{ThO}_{2}$ particles as markers at the $\mathrm{Cu} / \mathrm{Cu}_{6} \mathrm{Sn}_{5}$ diffusion couple interface. After isothermal aging at $215{ }^{\circ} \mathrm{C}$ for $225 \mathrm{~h}$, they found that the $\mathrm{ThO}_{2}$ particles were located in the inner $\mathrm{Cu}_{3} \mathrm{Sn}$ layer, indicating that $\mathrm{Cu}_{3} \mathrm{Sn}$ grew to both the $\mathrm{Cu}$ substrate and $\mathrm{Cu}_{6} \mathrm{Sn}_{5}$ side. Our observations here are consistent with their results. In addition, it was found that the linear slope of the $\mathrm{Cu}_{3} \mathrm{Sn} / \mathrm{Cu}$ interface (line $l_{3}$ (Figure 5b)) was higher than that of the $\mathrm{Cu}_{6} \mathrm{Sn}_{5} / \mathrm{Cu}_{3} \mathrm{Sn}$ interface (line $l_{2}$ ). This indicated that the growth rate of $\mathrm{Cu}_{3} \mathrm{Sn}$ on the $\mathrm{Cu}$ substrate side was higher than that on the side of $\mathrm{Cu}_{6} \mathrm{Sn}_{5}$ during isothermal aging. It was reported that the diffusion rate of $\mathrm{Sn}$ atoms from the solder seam to the $\mathrm{Cu}$ substrate was faster than that of the $\mathrm{Cu}$ atoms from the $\mathrm{Cu}$ substrate to the $\mathrm{Cu}_{6} \mathrm{Sn}_{5} / \mathrm{Cu}_{3} \mathrm{Sn}$ interface at the higher temperature $\left(\geq 170^{\circ} \mathrm{C}\right)$ in the $\mathrm{Sn}-\mathrm{Cu}$ couple experiment [37]. Therefore, the growth rate of $\mathrm{Cu}_{3} \mathrm{Sn}$ on the $\mathrm{Cu}$ substrate side was higher than that on the side of $\mathrm{Cu}_{6} \mathrm{Sn}_{5}$ during isothermal aging. Figure $5 \mathrm{~d}$ shows a schematic illustration of the interfacial movement of $\mathrm{Sn} 2.5 \mathrm{Ag} 0.7 \mathrm{Cu} 0.1 \mathrm{RE} / \mathrm{Cu}$ solder joints during isothermal aging. The arrow markers $\mathrm{A}-\mathrm{A}, \mathrm{B}-\mathrm{B}$, and $\mathrm{C}-\mathrm{C}$ represent the movement direction of the solder seam $/ \mathrm{Cu}_{6} \mathrm{Sn}_{5}, \mathrm{Cu}_{6} \mathrm{Sn}_{5} / \mathrm{Cu}_{3} \mathrm{Sn}$, and $\mathrm{Cu}_{3} \mathrm{Sn} / \mathrm{Cu}$ interfaces, respectively. We can conclude that the interface IMC becomes a double-layer consisting of $\mathrm{Cu}_{3} \mathrm{Sn}$ and $\mathrm{Cu}_{6} \mathrm{Sn}_{5} \mathrm{IMC}$, and the $\mathrm{Cu}_{3} \mathrm{Sn}$ IMC grows towards both the solder seam and $\mathrm{Cu}$ substrate simultaneously during the isothermal aging as illustrated in Figure 6. 

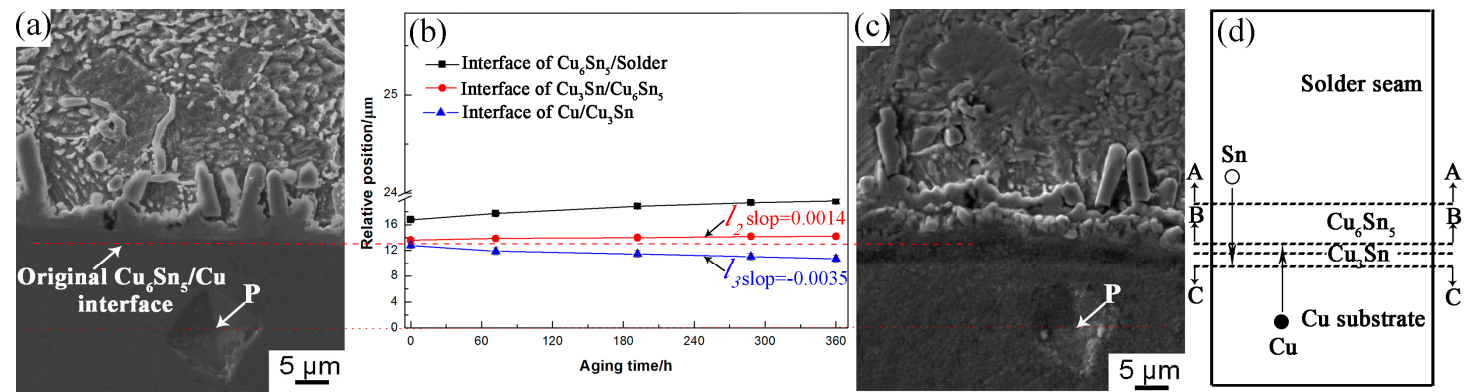

Figure 5. Interface position as a function of aging time and schematic illustration of the interfacial movement during aging: (a) after soldering, (b) interface position as a function of aging time, (c) isothermal aging $360 \mathrm{~h}$, and (d) the schematic illustration of the interfacial movement.

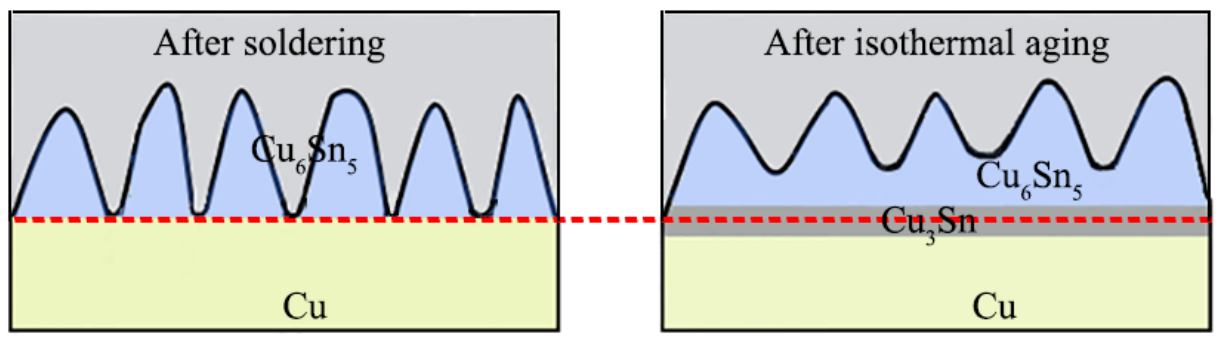

Figure 6. Schematic illustration of the interfacial IMC during isothermal aging.

\subsection{Interfacial IMC Growth Kinetics of the Sn2.5Ag0.7Cu0.1RE/Cu Solder Joints during Isothermal Aging}

Figure 7 displays the thickness of the interfacial IMC layer isothermal aged for different times and temperatures. The interfacial IMC evolved from a single $\mathrm{Cu}_{6} \mathrm{Sn}_{5}$ layer after soldering to a $\mathrm{Cu}_{6} \mathrm{Sn}_{5}$ and $\mathrm{Cu}_{3} \mathrm{Sn}$ IMC double layers during the isothermal aging process. At the isothermal aging temperatures of $100,125,150$, and $175{ }^{\circ} \mathrm{C}$, the thickness of $\mathrm{Cu}_{6} \mathrm{Sn}_{5}$ and $\mathrm{Cu}_{3} \mathrm{Sn}$ IMC increased with prolonged aging time. In addition, with increasing isothermal aging temperature, the thickness of $\mathrm{Cu}_{6} \mathrm{Sn}_{5}$ and $\mathrm{Cu}_{3} \mathrm{Sn}$ IMC also increased.

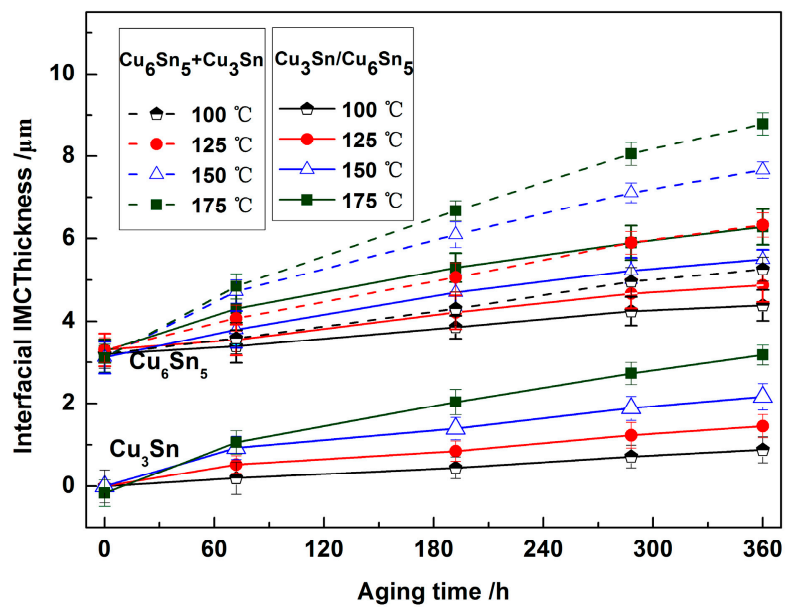

Figure 7. The thickness of interfacial IMC for different aging time and temperature.

To further study the growth kinetics of $\mathrm{Cu}_{6} \mathrm{Sn}_{5}$ and $\mathrm{Cu}_{3} \mathrm{Sn}$ IMC, we investigated the growth behavior of $\mathrm{Cu}_{6} \mathrm{Sn}_{5}$ and $\mathrm{Cu}_{3} \mathrm{Sn}$ IMC during isothermal aging at $175^{\circ} \mathrm{C}$. During isothermal aging, the growth of the interfacial IMC layer had a diffusion-controlled mechanism, and the growth kinetics parameter was calculated by measuring the interfacial thickness as a function of the isothermal aging 
time. The relationship between the interfacial IMC layer thickness and the aging time can be expressed as follows [38]:

$$
d_{x}=K t^{n}+d_{0}
$$

In Equation (2), $d_{x}$ presented the thickness of the interface IMC layer at a time $(t), d_{0}$ is the initial thickness of the interfacial IMC layer after soldering, $K$ is the growth constant $\left(\mathrm{mm}^{2} / \mathrm{s}\right)$ that is related to the diffusion coefficient of the atoms, and $\mathrm{n}$ is the time exponent. The value of $\mathrm{n}$ can be determined by a multivariable linear regression analysis of Equation (2) when placed in the following format:

$$
\ln \left(d_{x}-d_{0}\right)=\ln K+n \ln t
$$

The time exponent $\mathrm{n}$ was obtained from the slope of the $\ln \left(d_{x}-d_{0}\right)$ versus $\ln t$ plot in Figure 8 . In this study, the values of the time exponent $n$ of $\mathrm{Cu}_{6} \mathrm{Sn}_{5}+\mathrm{Cu}_{3} \mathrm{Sn}, \mathrm{Cu}_{6} \mathrm{Sn}_{5}$, and $\mathrm{Cu}_{3} \mathrm{Sn}$ were 0.49, 0.53 , and 0.51 , respectively, which are close to 0.5 . It has been reported that if the value of the time exponent is 0.33 , the growth of the interfacial IMC had a grain-boundary diffusion mechanism, whereas if the time exponent is 0.5 , the growth of the interfacial IMC had a bulk diffusion mechanism [39]. This indicated that the growth of $\mathrm{Cu}_{6} \mathrm{Sn}_{5}$ and $\mathrm{Cu}_{3} \mathrm{Sn}$ IMC layer during the isothermal aging process was controlled by the bulk diffusion mechanism. Then, Equation (3) can be expressed as follows:

$$
d_{x}=K t^{1 / 2}+d_{0} .
$$

From Equation (4), the thickness of the interfacial IMC was plotted against the root of the isothermal aging time $(t)$. Figure 9 shows the thickness of $\left(\mathrm{Cu}_{6} \mathrm{Sn}_{5}+\mathrm{Cu}_{3} \mathrm{Sn}_{2}\right) \mathrm{Cu}_{6} \mathrm{Sn}_{5}$, and $\mathrm{Cu}_{3} \mathrm{Sn}$ against the square root of the isothermal aging time. The thickness of the interfacial IMC showed a linear relationship. The value of the growth constant $(K)$ was obtained by the slope of the linear regression. The growth constants of the interface $\left(\mathrm{Cu}_{6} \mathrm{Sn}_{5}+\mathrm{Cu}_{3} \mathrm{Sn}\right), \mathrm{Cu}_{6} \mathrm{Sn}_{5}$, and $\mathrm{Cu}_{3} \mathrm{Sn}$ were $K_{\mathrm{Cu} 6 \mathrm{Sn} 5+\mathrm{Cu} 3 \mathrm{Sn}}=2.34 \times 10^{-17} \mathrm{~m}^{2} / \mathrm{s}$, $K_{C u 6 S n 5}=6.25 \times 10^{-18} \mathrm{~m}^{2} / \mathrm{s}$, and $K_{C u 3 S n}=7.11 \times 10^{-18} \mathrm{~m}^{2} / \mathrm{s}$, respectively. The growth constant of $\mathrm{Cu}_{3} \mathrm{Sn}$ was slightly higher than that of $\mathrm{Cu}_{6} \mathrm{Sn}_{5}$, which indicated that the growth rate of $\mathrm{Cu}_{3} \mathrm{Sn}$ was higher than that of $\mathrm{Cu}_{6} \mathrm{Sn}_{5}$ with aging time. This result was consistent with the dynamic observation of interfacial IMC growth.

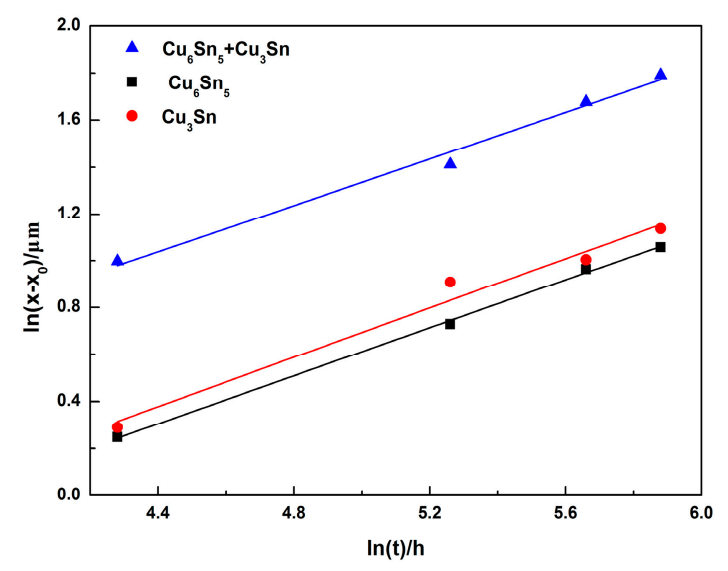

Figure 8. Plot of $\ln \left(d_{x}-d_{0}\right)$ versus $\ln (t)$. 


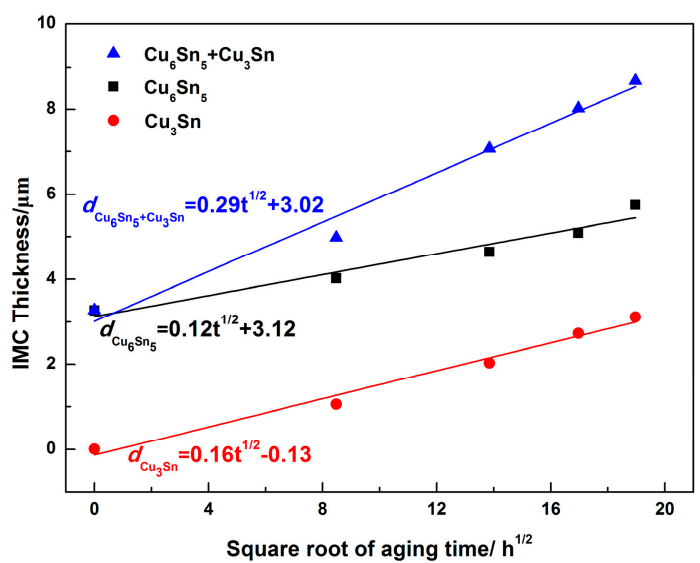

Figure 9. Linear fit of interfacial IMC thickness versus square root of aging time.

During the isothermal aging process, the growth of interfacial $\mathrm{Cu}_{6} \mathrm{Sn}_{5}$ and $\mathrm{Cu}_{3} \mathrm{Sn}$ IMC was controlled by the interdiffusion of $\mathrm{Cu}$ and $\mathrm{Sn}$ atoms. The activation energies for $\mathrm{Cu}_{6} \mathrm{Sn}_{5}$ and $\mathrm{Cu} 3 \mathrm{Sn}$ can be calculated by the Arrhenius relationship [40]:

$$
K=K_{0} * \exp (-Q / R T),
$$

where $K$ is the growth constant $\left(\mathrm{mm}^{2} / \mathrm{s}\right), K_{0}$ is the frequency factor, $Q$ is the activation energy, $R$ is the gas constant $(8.314 \mathrm{~J} / \mathrm{mol} / \mathrm{K})$, and $T$ is the aging temperature. The activation energies can be obtained from the slope of the $\ln (K)$ versus $\ln (1 / T)$ plot. Figure 10 shows the Arrhenius plots of the interfacial IMC growth, and the activation energies values of $\mathrm{Cu}_{6} \mathrm{Sn}_{5}$ and $\mathrm{Cu}_{3} \mathrm{Sn}$ were 74.7 and $86.6 \mathrm{~kJ} / \mathrm{mol}$, respectively. This result is close to the values of 69.42 and $91.88 \mathrm{~kJ} / \mathrm{mol} \mathrm{for} \mathrm{Cu}_{6} \mathrm{Sn}_{5}$ and $\mathrm{Cu}_{3} \mathrm{Sn}$, respectively, in $\mathrm{Sn3} .0 \mathrm{Ag} 0.5 \mathrm{Cu} / \mathrm{Cu}$ solder joints during isothermal aging [41]. It was obvious that the activation energy of $\mathrm{Cu}_{3} \mathrm{Sn}$ was higher than that of $\mathrm{Cu}_{6} \mathrm{Sn}_{5}$, which indicated that the growth of $\mathrm{Cu}_{3} \mathrm{Sn}$ IMC was difficult.

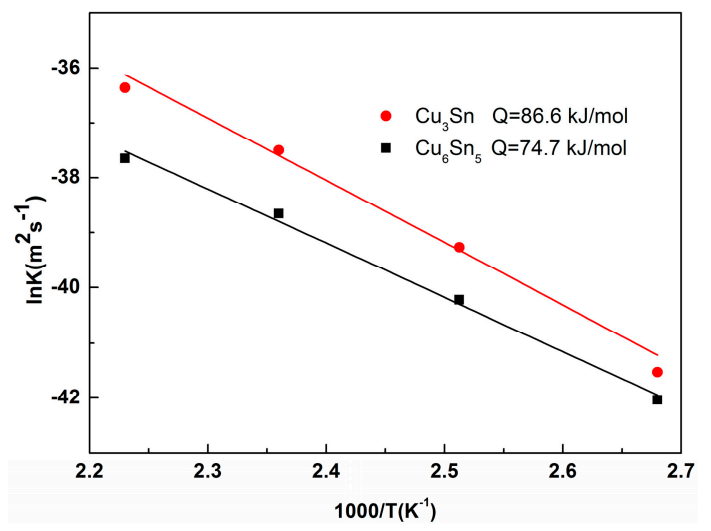

Figure 10. Arrhenius plot of the IMC layer growth during isothermal aging.

The growth of interfacial $\mathrm{Cu}_{3} \mathrm{Sn}$ IMC depends on the temperature increase and the prolonged time. During the soldering process, the soldering time was so short that it could not provide the growth condition for $\mathrm{Cu}_{3} \mathrm{Sn}$ IMC with high activation energy. However, during the isothermal aging process, the heat preservation and long period satisfied the growth conditions of $\mathrm{Cu}_{3} \mathrm{Sn}$. Therefore, the isothermal aging process provided growth conditions for $\mathrm{Cu}_{3} \mathrm{Sn}$. This is in accordance with the formation of the $\mathrm{Cu}_{3} \mathrm{Sn}$ phase requiring an extended reaction time during the isothermal aging process [42]. It was reported that the growth rate of interfacial IMC is dependent on the activation energy when the supply of both the $\mathrm{Sn}$ and $\mathrm{Cu}$ atoms is sufficient [43]. During the soldering process, there was a liquid-state reaction, where the liquid phase $S n$ atoms of the soldering seam and solid-phase 
$\mathrm{Cu}$ atoms of the substrate were in full and direct contact with each other. The growth rate of interfacial $\mathrm{Cu}_{6} \mathrm{Sn}_{5}$ and $\mathrm{Cu}_{3} \mathrm{Sn}$ IMC mainly depends on the activation energy. However, during the isothermal aging process, the formation of $\mathrm{Cu}_{6} \mathrm{Sn}_{5}$ IMC after soldering may be a barrier for the diffusion of $\mathrm{Cu}$ and $\mathrm{Sn}$ atoms. In particular, the $\mathrm{Sn}$ atoms require long-range diffusion across the $\mathrm{Cu}_{6} \mathrm{Sn}_{5} \mathrm{IMC}$ layer to react with the substrate $\mathrm{Cu}$ atoms to form a $\mathrm{Cu}_{3} \mathrm{Sn} \mathrm{IMC,} \mathrm{which} \mathrm{makes} \mathrm{it} \mathrm{more} \mathrm{difficult} \mathrm{for} \mathrm{Cu}_{3} \mathrm{Sn}$ IMC to grow. However, the growth rate of the $\mathrm{Cu}_{3} \mathrm{Sn}$ IMC was slightly faster than that of the $\mathrm{Cu}_{6} \mathrm{Sn}_{5} \mathrm{IMC}$ during isothermal aging. This may be attributed to the $\mathrm{Cu}_{3} \mathrm{Sn}$ growth towards both the Cu substrate and solder seam sides. On the $\mathrm{Cu}_{6} \mathrm{Sn}_{5} / \mathrm{Cu}_{3} \mathrm{Sn}$ interface, the $\mathrm{Cu}_{3} \mathrm{Sn}$ grows at the expense of $\mathrm{Cu}_{6} \mathrm{Sn}_{5}$ according to reaction 1 , while on the $\mathrm{Cu}_{3} \mathrm{Sn} / \mathrm{Cu}$ interface, the growth of $\mathrm{Cu}_{3} \mathrm{Sn}$ can be expressed by reaction 2 . The growth of $\mathrm{Cu}_{6} \mathrm{Sn}_{5}$ mainly depended on the reaction $6 \mathrm{Cu}+5 \mathrm{Sn}=\mathrm{Cu}_{6} \mathrm{Sn}_{5}$. The $\mathrm{Cu}$ atoms on the solder seam were in the form of a eutectic structure. A very small amount of free $\mathrm{Cu}$ atoms can diffuse to the $\mathrm{Cu}_{6} \mathrm{Sn}_{5} /$ solder seam interface. At the same time, at the $\mathrm{Cu}_{6} \mathrm{Sn}_{5} / \mathrm{Cu}_{3} \mathrm{Sn}$ interface, the growth of $\mathrm{Cu}_{3} \mathrm{Sn}$ IMC consumed a certain amount of $\mathrm{Cu}$ atoms diffused from the $\mathrm{Cu}$ substrate, which may lead to a reduction in the amount of diffusion $\mathrm{Cu}$ atoms from the $\mathrm{Cu}$ substrate to the $\mathrm{Cu}_{6} \mathrm{Sn}_{5}$ /solder seam interface, resulting in a limited growth rate of $\mathrm{Cu}_{6} \mathrm{Sn}_{5}$.

\subsection{Mechanical Properties of the Sn2.5Ag0.7Cu0.1RE/Cu Solder Joints during Isothermal Aging}

Figure 11 displays the shear strength of the $\mathrm{Sn} 2.5 \mathrm{Ag} 0.7 \mathrm{Cu} 0.1 \mathrm{RE} / \mathrm{Cu}$ solder joints for different isothermal aging times and temperatures. With the increase of isothermal aging time and temperature, the shear strength of the solder joints decreased, and the thickness of the interfacial IMC increased (Figure 7). Because of the brittleness of the $\mathrm{Cu}_{3} \mathrm{Sn}$ and $\mathrm{Cu}_{6} \mathrm{Sn}_{5} \mathrm{IMC}$, the increase in interfacial IMC thickness may deteriorate the mechanical properties of the solder joints. Additionally, during the isothermal aging process, the Kirkendall voids appeared in the $\mathrm{Cu}_{3} \mathrm{Sn} \mathrm{IMC}$, which is also harmful to the shear strength of the solder joint. To determine the relationship between the shear strength of the solder joints and interfacial IMC thickness, Figure 12 shows the multivariable regression analysis of the shear strength and thickness of the interfacial IMC. The shear strength of the solder joints was linearly correlated with the thickness of $\mathrm{Cu}_{6} \mathrm{Sn}_{5}$, which indicated that the thickness of $\mathrm{Cu}_{3} \mathrm{Sn}$ has a direct relation with the shear strength of the joints.

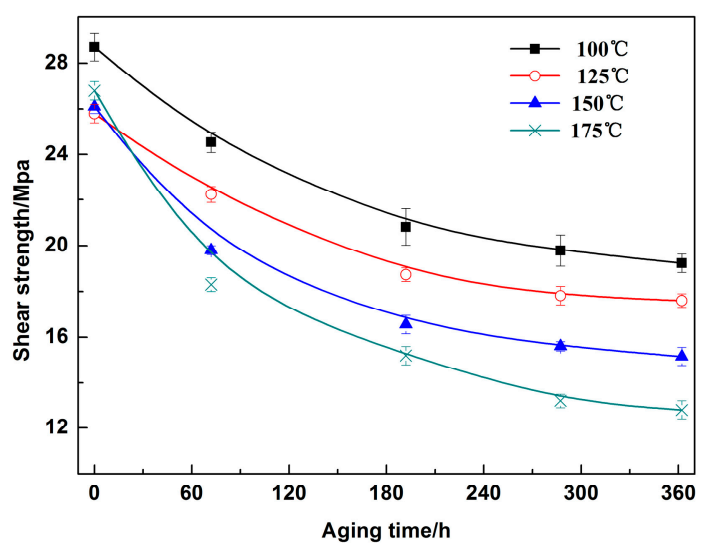

Figure 11. Shear strength of the solder joints for different aging time and temperature. 


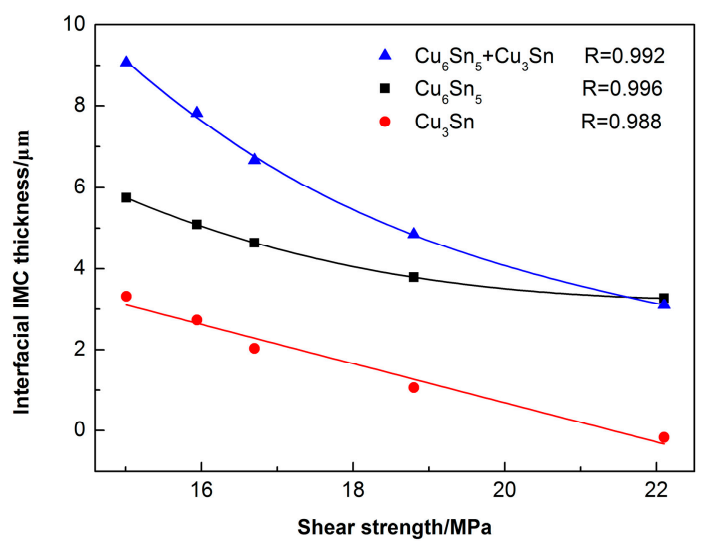

Figure 12. Relationship between shear strength and interfacial $\mathrm{Cu}_{6} \mathrm{Sn}_{5}$ and $\mathrm{Cu}_{3} \mathrm{Sn}$ thickness.

Figure 13 presents the shear fracture surface of the solder joints aged at $175{ }^{\circ} \mathrm{C}$ for a different time. The fracture surface displayed typical parabolic-shaped dimples after soldering, as shown in Figure 13a. These parabolic-shaped dimples indicated ductile fracture. With increasing aging time, the number of parabolic dimples decreased, and the cleavage planes appeared in the fracture surface after isothermal aging for $192 \mathrm{~h}$ as illustrated in Figure 13b. After aging for $360 \mathrm{~h}$ (Figure 13c), the fracture surface was dominated by the cleavage planes, and micro-cracks occurred, which indicated the brittle fracture manner. The composition of " $\mathrm{A}$ ", " $\mathrm{B}$ ", and " $\mathrm{C}$ " areas are listed in Table 1 . The area " $\mathrm{A}$ " contained mainly $\mathrm{Sn}$, whereas the areas " $\mathrm{B}$ " and " $\mathrm{C}$ " consisted of $\mathrm{Sn}$ and $\mathrm{Cu}$, and the mole ratio of $\mathrm{Cu}$ to $\mathrm{Sn}$ was approximately 3:1 and 6:5, respectively. Thus, the cleavage plane may be the $\mathrm{Cu}_{6} \mathrm{Sn}_{5}$ and $\mathrm{Cu}_{3} \mathrm{Sn}$ IMC. We can deduce that with increasing isothermal aging time, the fracture mechanism transformed from the ductile-type fracture mechanism with the dominant parabolic-shaped dimples in the solder seam to brittle fracture with the cleavage of the interfacial $\mathrm{Cu}_{6} \mathrm{Sn}_{5}$ and $\mathrm{Cu}_{3} \mathrm{Sn}$ IMC. Figure 14 shows the XRD pattern of the fracture surface of the solder joints aged at various times. Compared with the sample after soldering, the intensity of the $\mathrm{Cu}_{6} \mathrm{Sn}_{5}$ peak is higher, and the ratio of the $\mathrm{Cu}_{6} \mathrm{Sn}_{5}$ to $\beta$-Sn peak becomes gradually higher with increasing isothermal aging time. Additionally, the intensity of the $\mathrm{Cu}_{3} \mathrm{Sn}$ peak increased with prolonged aging time. This indicated that the fracture pathway transferred from the solder seam to the interfacial IMC, which was near the side of the $\mathrm{Cu}_{3} \mathrm{Sn}$ IMC layer. This result is consistent with the above shear fracture morphology analysis. The change in the fracture pathway was mainly attributed to the increase of interfacial IMC thickness during the isothermal aging process. In general, the coefficient of thermal expansion (CTE) between the interfacial IMC layer $\left(1.84 \times 10^{-5} \mathrm{~m} / \mathrm{K}\right)$ and $\mathrm{Cu}$ substrate $\left(1.67 \times 10^{-6} \mathrm{~m} / \mathrm{K}\right)$ was mismatched, leading to a stress concentration during long isothermal aging [44]. Hence, the micro-cracks occurred and propagated along with the interface. In addition, we also found that with increasing isothermal aging temperature, the fracture pathway shifted from the solder seam to the direction of the interfacial IMC layer.
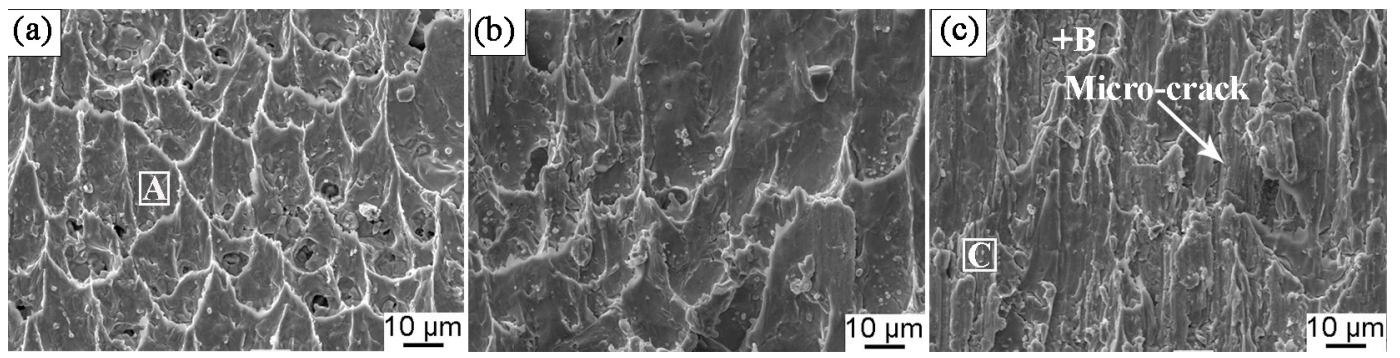

Figure 13. The shear fracture surface of the solder joints aged at $175{ }^{\circ} \mathrm{C}$ for a different time: (a) $0 \mathrm{~h}$, (b) $192 \mathrm{~h}$, and (c) $360 \mathrm{~h}$. 
Table 1. EDS analysis results of the " $\mathrm{A}$ ", " $\mathrm{B}$ ", and " $\mathrm{C}$ " areas in Figure 13.

\begin{tabular}{cccc}
\hline \multirow{2}{*}{ Area } & \multicolumn{3}{c}{ Mole Fraction/\% } \\
\cline { 2 - 4 } & Sn & Cu & Ag \\
\hline A & 93.49 & 5.34 & 1.18 \\
B & 24.72 & 75.28 & - \\
C & 46.64 & 53.36 & - \\
\hline
\end{tabular}

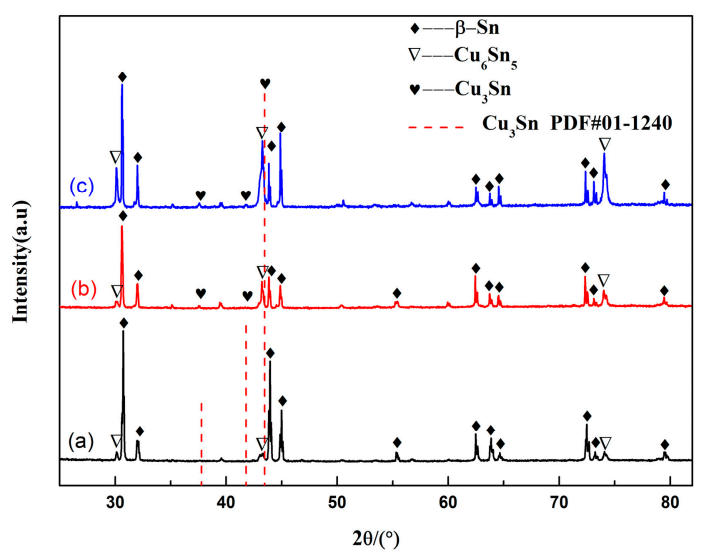

Figure 14. XRD analysis results of the fracture surface aged at $175^{\circ} \mathrm{C}$ with different aging times: (a) $0 \mathrm{~h}$, (b) $192 \mathrm{~h}$, and (c) $360 \mathrm{~h}$.

\section{Conclusions}

In this study, the microstructure evolution of the interfacial IMC and the mechanical properties of $\mathrm{Sn} 2.5 \mathrm{Ag} 0.7 \mathrm{Cu} 0.1 \mathrm{RE} / \mathrm{Cu}$ solder joints during the isothermal aging process were investigated by dynamic observation. The conclusions can be summarized as follows.

1. During the isothermal aging process of $S n 2.5 \mathrm{Ag} 0.7 \mathrm{Cu} 0.1 \mathrm{RE} / \mathrm{Cu}$ lead-free solder joints, interfacial IMC evolved from single $\mathrm{Cu}_{6} \mathrm{Sn}_{5}$ to $\mathrm{Cu}_{6} \mathrm{Sn}_{5}$ and $\mathrm{Cu}_{3} \mathrm{Sn}$ double layers. The $\mathrm{Cu}_{3} \mathrm{Sn}$ grew towards the $\mathrm{Cu}$ substrate and the solder seam sides; growth toward the $\mathrm{Cu}$ substrate side was dominant. The growth of the $\mathrm{Cu}_{3} \mathrm{Sn}$ IMC was depended on prolonged time at a certain temperature. Additionally, the growth of the interfacial IMC was mainly controlled by the bulk diffusion mechanism, and the activation energy values of $\mathrm{Cu}_{6} \mathrm{Sn}_{5}$ and $\mathrm{Cu}_{3} \mathrm{Sn}$ were 74.7 and $86.6 \mathrm{~kJ} / \mathrm{mol}$, respectively. The growth rate of $\mathrm{Cu}_{3} \mathrm{Sn}$ was slightly faster than that of $\mathrm{Cu}_{6} \mathrm{Sn}_{5}$ during the isothermal aging process.

2. With increasing isothermal aging time and temperature, the shear strength of the solder joints decreased, which was linearly related to the thickness of the interfacial $\mathrm{Cu}_{3} \mathrm{Sn} \mathrm{IMC}$. Additionally, the fracture mechanism of the solder joints changed from ductile fracture, which contained dimples, to brittle fracture, which contained cleavage planes; the fracture pathway also moved from the solder seam to the interfacial IMC layer, which was close to the $\mathrm{Cu}_{3} \mathrm{Sn}$ IMC.

Author Contributions: D.Z. and K.Z. conceived and designed the experiments, C.Y. and S.L. contributed to the process of the preparation of samples; F.H. analyzed formal, D.Z. wrote the paper, K.Z. and N.M. revised the paper, Funding Acquisition, K.Z. All authors have read and agreed to the published version of the manuscript.

Funding: This work was financially supported by the National Natural Science Foundation of China under Grant No. U1604132, the Plan for Scientific Innovation Talent of Henan Province under Grant No. 154200510022, the National Science and Technology International Cooperation of China under Grant No. 2014DFR50820 and the Collaborative Innovation Center of Non-ferrous Metals, Henan Province, China.

Conflicts of Interest: All of the authors declare that we have no conflict of interest.

\section{References}

1. Teo, J.W.R.; Sun, Y.F. Spalling behavior of interfacial intermetallic compounds in Pb-free solder joints subjected to temperature cycling loading. Acta Mater. 2008, 56, 242-249. [CrossRef] 
2. Hu, X.; Li, C.; Li, Q.; Yi, G. Insights on interfacial IMCs growth and mechanical strength of asymmetrical $\mathrm{Cu} / \mathrm{SAC} 305 / \mathrm{Cu}-\mathrm{Co}$ system. Vacuum 2019, 167, 77-89. [CrossRef]

3. Wang, F.J.; Chen, H.; Huang, Y.; Liu, L.T.; Zhang, Z.J. Recent progress on the development of Sn-Bi based low-temperature Pb-free solders. J. Mater. Sci-Mater. Electron. 2019, 30, 3222-3243. [CrossRef]

4. Wang, H.; Zhang, K.; Zhang, M. Fabrication and properties of Ni-modified graphene nanosheets reinforced Sn-Ag-Cu composite solder. J. Alloys Compd. 2019, 781, 761-772. [CrossRef]

5. Gain, A.K.; Zhang, L.; Quadir, M.Z. Thermal aging effects on microstructures and mechanical properties of an environmentally friendly eutectic tin-copper solder alloy. Mater. Des. 2016, 110, 275-283. [CrossRef]

6. Zhang, M.; Zhang, K.K.; Huo, F.P.; Wang, H.G.; Wang, Y. Microstructures and Properties of $S_{2 n}{ }_{2.5} A_{0.7} C_{0.1} R E$ Composite Solders Reinforced with Cu-Coated Graphene Nanosheets Synthesized by Pyrolysis. Materials 2019, 12, 289. [CrossRef]

7. Kotadia, H.R.; Howes, P.D.; Mannan, S.H. A review: On the development of low melting temperature Pb-free solders. Microelectron. Reliab. 2014, 54, 1253-1273. [CrossRef]

8. Wu, J.; Xue, S.B.; Wang, J.W.; Liu, S.; Wang, L.J. Recent progress of Sn-Ag-Cu lead-free solders bearing alloy elements and nanoparticles in electronic packaging. J. Mater. Sci. Mater. Electron. 2016, 27, 1-35. [CrossRef]

9. Ma, C.L.; Xue, S.B.; Wang, B.; Long, W.M.; Zhong, S.J. Effects of Ga and Ce on the Microstructure and Properties of Cadmium-free Silver Filler Metals. Rare Metal. Mat. Eng. 2019, 48, 91-96.

10. Wang, B.; Xue, S.B.; Wang, J.X.; Long, W.M.; Zhang, Q.K. Effect of Rare Earth Pr on Creep Behavior of Sn-0.3Ag-0.7Cu-0.5Ga Low-Ag Solder Alloys. Rare Met. Mater. Eng. 2018, 47, 2657-2662.

11. Han, Y.; Xue, S.; Yang, J.; Long, W.; Zhang, Q. Effects of trace amount praseodymium and neodymium on microstructure and mechanical properties of $\mathrm{Sn}_{-0.3} \mathrm{Ag}_{-0.7} \mathrm{Cu}_{-0.5} \mathrm{Ga}$ solder. J. Mater. Sci. Mater. Electron. 2016, 27, 351-358. [CrossRef]

12. Dudek, M.A.; Chawla, N. Effect of Rare-Earth (La, Ce, and Y) Additions on the Microstructure and Mechanical Behavior of $\mathrm{Sn}_{-3.9} \mathrm{Ag}_{-0.7} \mathrm{Cu}$ Solder Alloy. Metall. Mater. Trans. A 2010, 41, 610-620. [CrossRef]

13. Law, C.M.T.; Wu, C.M.L.; Yu, D.Q.; Wang, L.; Lai, J.K.L. Microstructure, solderability, and growth of intermetallic compounds of Sn-Ag-Cu-RE lead-free solder alloys. J. Electron. Mater. 2006, 35, 89-93. [CrossRef]

14. Yu, D.Q.; Zhao, J.; Wang, L. Improvement on the microstructure stability, mechanical and wetting properties of Sn-Ag-Cu lead-free solder with the addition of rare earth elements. J. Alloys Compd. 2004, 376, 170-175. [CrossRef]

15. Zhang, K.; Wang, S.; Yu, Y.; Wang, Y.; Fan, Y.; Cheng, G.; Han, L. Wetting match performance of SnAgCuRE lead-free solder for surface mount component. Chin. J. Nonferrous Met. 2006, 16, 1908-1912.

16. Zhang, K.; Wang, Y.; Fan, Y.; Zhu, Y.; Zhang, X. Effect of Ce-La Mixed Rare Earth Content and Environment Conditions on the Creep Rupture Life of SnAgCu Solder Joints. Rare Metal. Mat. Eng. 2007, 36, 1473-1476.

17. Moore, A.L.; Shi, L. Emerging challenges and materials for thermal management of electronics. Mater. Today 2014, 17, 163-174. [CrossRef]

18. Gain, A.K.; Zhang, L. Harsh service environment effects on the microstructure and mechanical properties of Sn-Ag-Cu-1 wt\% nano-Al solder alloy. J. Mater. Sci. Mater. Electron. 2016, 27, 11273-11283. [CrossRef]

19. Cao, C.C.; Zhang, K.K.; Shi, B.J.; Wang, H.G.; Zhao, D.; Sun, M.M.; Zhang, C. The Interface Microstructure and Shear Strength of $\mathrm{Sn}_{2.5} \mathrm{Ag}_{0.7} \mathrm{Cu}_{0.1} \mathrm{RExNi} / \mathrm{Cu}$ Solder Joints under Thermal-Cycle Loading. Metals 2019, 7, 518. [CrossRef]

20. Zhang, L.; Han, J.; He, C.; Guo, Y. Reliability behavior of lead-free solder joints in electronic components. J. Mater. Sci. Mater. Electron. 2013, 24, 172-190. [CrossRef]

21. Xu, T.; Hu, X.; Li, Y.; Jiang, X. The growth behavior of interfacial intermetallic compound between $\mathrm{Sn}_{-3.5} \mathrm{Ag}_{-0.5} \mathrm{Cu}$ solder and $\mathrm{Cu}$ substrate under different thermal-aged conditions. J. Mater. Sci. Mater. Electron. 2017, 25, 1-14. [CrossRef]

22. Zhang, L.; Fan, X.; He, C.; Guo, Y. Intermetallic compound layer growth between SnAgCu solder and $\mathrm{Cu}$;substrate in electronic packaging. J. Mater. Sci. Mater. Electron. 2013, 24, 3249-3254. [CrossRef]

23. Hu, X.; Xu, T.; Keer, L.M.; Li, Y.; Jiang, X. Microstructure evolution and shear fracture behavior of aged $\mathrm{Sn}_{3} \mathrm{Ag}_{0.5} \mathrm{Cu} / \mathrm{Cu}$ solder joints. Mater. Sci. Eng. A 2016, 673, 167-177. [CrossRef]

24. $\mathrm{Hu}, \mathrm{X} . ; \mathrm{Xu}, \mathrm{T}$; Keer, L.M.; Li, Y.; Jiang, X. Shear strength and fracture behavior of reflowed $\mathrm{Sn3} .0 \mathrm{Ag} 0.5 \mathrm{Cu} / \mathrm{Cu}$ solder joints under various strain rates. J. Alloys Compd. 2017, 690, 720-729. [CrossRef] 
25. Nishikawa, H.; Iwata, N. Formation and growth of intermetallic compound layers at the interface during laser soldering using Sn-Ag Cu solder on a Cu Pad. J. Mater. Process. Technol. 2015, 215, 6-11. [CrossRef]

26. Kim, D.G.; Jung, S.B. Interfacial reactions and growth kinetics for intermetallic compound layer between In-48Sn solder and bare Cu substrate. J. Alloys Compd. 2005, 386, 151-156. [CrossRef]

27. Tian, F.; Li, C.F.; Zhou, M.; Liu, Z.Q. The interfacial reaction between In-48Sn solder and polycrystalline Cu substrate during solid state aging. J. Alloys Compd. 2018, 740, 500-509. [CrossRef]

28. Wang, F.; Zhou, L.; Wang, X.; He, P. Microstructural evolution and joint strength of Sn-58Bi/Cu joints through minor Zn alloying substrate during isothermal aging. J. Alloys Compd. 2016, 688, 639-648. [CrossRef]

29. Wang, F.; Huang, Y.; Zhang, Z.; Yan, C. Interfacial Reaction and Mechanical Properties of Sn-Bi Solder joints. Materials 2017, 10, 920. [CrossRef]

30. Zhao, D.; Zhang, K.; Cui, J.; Ma, N.; Pan, Y.; Yin, C. Effect of ultrasonic vibration on the interfacial IMC three-dimensional morphology and mechanical properties of $\mathrm{Sn}_{2.5} \mathrm{Ag}_{0.7} \mathrm{Cu}_{0.1} \mathrm{RE}_{0.05} \mathrm{Ni} / \mathrm{Cu}$ halogen free solder joints. J. Mater. Sci. Mater. Electron. 2018, 29, 18828-18839. [CrossRef]

31. Huo, F.; Zhang, K.; Zhang, M.; Wang, H. The interfacial intermetallic and shear strength of Ni nanoparticle-decorated reduced graphene oxide reinforced $\mathrm{Sn}_{2.5} \mathrm{Ag}_{0.5} \mathrm{Cu}$ lead-free composite soldering joints. Adv. Eng. Mater. 2018, 20, 1800147-1800155. [CrossRef]

32. El-Daly, A.A.; Desoky, W.M.; Elmosalami, T.A.; El-Shaarawy, M.G.; Abdraboh, A.M. Microstructural modifications and properties of $\mathrm{SiC}$ nanoparticles-reinforced $\mathrm{Sn}_{-3.0} \mathrm{Ag}_{-0.5} \mathrm{Cu}$ solder alloy. Mater. Des. 2015, 65, 1196-1204. [CrossRef]

33. Cui, J.G.; Zhang, K.K.; Zhao, D.; Ma, N.; Cao, C.C.; Pan, Y.B. Microstructure and properties of $\mathrm{Sn}_{2.5} \mathrm{Ag}_{0.7} \mathrm{Cu}_{0.1} \mathrm{RE}_{0.05} \mathrm{Ni} / \mathrm{Cu}$ solder joints obtained by external energy assisted soldering. Rare Metal. Mat. Eng. 2018, 47, 2800-2806.

34. Peng, W.; Monlevade, E.; Marques, M.E. Effect of thermal aging on the interfacial structure of SnAgCu solder joints on Cu. Microelectron. Reliab. 2007, 47, 2161-2168. [CrossRef]

35. Zhang, Z.; Hu, X.; Jiang, X.; Li, Y. Influences of Mono-Ni(P) and Dual-Cu/Ni(P) Plating on the Interfacial Microstructure Evolution of Solder Joints. Metall. Mater. Trans. A 2019, 50, 480-492. [CrossRef]

36. Paul, A.; Laurila, T.; Vuorinen, V.; Divinski, S.V. Thermodynamics, Diffusion and the Kirkendall Effect in Solids; Springer: Berlin, Germany, 2014; pp. 115-139.

37. Deng, X.; Piotrowski, G.; Williams, J.J.; Chawla, N. Influence of initial morphology and thickness of $\mathrm{Cu}_{6} \mathrm{Sn}_{5}$ and $\mathrm{Cu}_{3} \mathrm{Sn}$ intermetallics on growth and evolution during thermal aging of Sn-Ag solder/Cu joints. J. Electron. Mater. 2003, 32, 1403-1413. [CrossRef]

38. Rizvi, M.J.; Chan, Y.C.; Bailey, C.; Lu, H.; Islam, M.N. Effect of adding 1 wt $\%$ Bi into the $\mathrm{Sn}_{-2.8} \mathrm{Ag}_{-0.5} \mathrm{Cu}$ solder alloy on the intermetallic formations with $\mathrm{Cu}$-substrate during soldering and isothermal aging. J. Alloys Compd. 2006, 407, 208-214. [CrossRef]

39. Yu, D.Q.; Wang, L. The growth and roughness evolution of intermetallic compounds of $\mathrm{Sn}-\mathrm{Ag}-\mathrm{Cu} / \mathrm{Cu}$ interface during soldering reaction. J. Alloys Compd. 2008, 458, 542-547. [CrossRef]

40. Zhang, L.; Xue, S.B.; Zeng, G.; Gao, L.L.; Ye, H. Interface reaction between SnAgCu/SnAgCuCe solders and $\mathrm{Cu}$ substrate subjected to thermal cycling and isothermal aging. J. Alloys Compd. 2012, 510, 38-45. [CrossRef]

41. Kim, Y.M.; Roh, H.R.; Kim, S.; Kim, Y.H. Kinetics of Intermetallic Compound Formation at the Interface Between $\mathrm{Sn}_{-3.0} \mathrm{Ag}_{-0.5} \mathrm{Cu}$ Solder and $\mathrm{Cu}-\mathrm{Zn}$ Alloy Substrates. J. Electron. Mater. 2010, 39, 2504-2512. [CrossRef]

42. Laurila, T.; Vuorinen, V.; Kivilahti, J.K. Interfacial reactions between lead-free solders and common base materials. Mater. Sci. Eng. R 2005, 49, 1-60. [CrossRef]

43. Tan, A.T.; Tan, A.W.; Yusof, F. Influence of nanoparticle addition on the formation and growth of intermetallic compounds (IMCs) in $\mathrm{Cu} / \mathrm{Sn}-\mathrm{Ag}-\mathrm{Cu} / \mathrm{Cu}$ solder joint during different thermal conditions. Sci. Technol. Adv. Mater. 2015, 16, 033505.

44. Shen, J.; Zhao, M.; He, P.; Pu, Y. Growth behaviors of intermetallic compounds at $\mathrm{Sn}_{-3} \mathrm{Ag}_{-0.5} \mathrm{Cu} / \mathrm{Cu}$ interface during isothermal and non-isothermal aging. J. Alloys Compd. 2013, 574, 451-458. [CrossRef]

(C) 2020 by the authors. Licensee MDPI, Basel, Switzerland. This article is an open access article distributed under the terms and conditions of the Creative Commons Attribution (CC BY) license (http://creativecommons.org/licenses/by/4.0/). 